\title{
PENELITIAN KHALAYAK DALAM PERSPEKTIF RECEPTION ANALYSIS
}

\author{
Ido Prijana Hadi \\ Jurusan Ilmu Komunikasi, Fakultas Ilmu Komunikasi \\ Universitas Kristen Petra \\ Jalan Siwalankerto 121-131 Surabaya, 60236 \\ Email:ido@petra.ac.id;
}

\begin{abstract}
Reception analysis provides a means of understanding media texts by understanding how these texts are read by audiences. Theorists who analyze media through reception studies are concerned with the experience of media (print, broadcasting, online media) and it takes a closer look at what is actually going on. Reception analysis concentrates on the audience themselves and how they come to a particular understanding view of a text, and how meaning is created through that experience. An important concept of reception theory is that the media text-the individual movie or television program - has no inherent meaning in and of itself. Instead, meaning is created in the interaction between spectator and text; in other words, meaning is created as the viewer watches and processes the movie. Reception theory argues that contextual factors, more than textual ones, influence the way the spectator views the movie or television program. Contextual factors include elements of the viewer's identity as well as circumstances of exhibition, the spectator's preconceived notions concerning the movie or television program's genre and production, and even broad social, historical, and political issues. In short, reception theory places the audience in context, taking into account all of the various factors that might influence how she or he will read and contruct meanings from the text, such as in form of still images, moving images, or written. To understand the meanings that people take from a text it is necessary to get closer to individual audience members and engage with them at a personal level-qualitative research becomes a necessity There are obvious implications for research methodology. Quantitative research is not suited to investigating the construction of meaning.
\end{abstract}

Keywords: Reception analysis, active audiences

\section{PENDAHULUAN}

Studi mengenai hubungan yang terjadi antara media dan khalayak (pembaca, pemirsa, pengguna internet) menjadi perhatian utama antara industri media, akademisi, maupun pemerhati media dan masalah sosial. Media mampu menjadi stimuli individu untuk menikmati sajian pesan atau program yang ditampilkan. Isi media mampu menjadi wacana perbincangan (penerimaan khalayak) yang menarik apabila dikaitkan dengan konteks budaya, misalnya efek dramatisasi visual yang ditimbulkan, pemirsa mampu mengkontruksi makna sesuai dengan teks dan konteks.

Salah satu standar untuk mengukur khalayak media adalah menggunakan reception analysis, dimana analisis ini mencoba memberikan sebuah makna atas 
pemahaman teks media (cetak, elektronik, internet) dengan memahami bagaimana karakter teks media dibaca oleh khalayak. Individu yang menganalisis media melalui kajian reception memfokuskan pada pengalaman dan pemirsaan khalayak (penonton/ pembaca), serta bagaimana makna diciptakan melalui pengalaman tersebut. Konsep teoritik terpenting dari reception analysis adalah bahwa teks media penonton/pembaca atau program televisi - bukan lah makna yang melekat pada teks media tersebut, tetapi makna diciptakan dalam interaksinya antara khalayak (penonton/ pembaca) dan teks. Dengan kata lain, makna diciptakan karena menonton atau membaca dan memproses teks media.

Teori reception mempunyai argumen bahwa faktor kontekstual mempengaruhi cara khalayak memirsa atau membaca media, misalnya film atau program televisi. Faktor kontekstual termasuk elemen identitas khalayak, persepsi penonton atas film atau genre program televisi dan produksi, bahkan termasuk latarbelakang sosial, sejarah dan isu politik. Singkatnya, teori reception menempatkan penonton/ pembaca dalam konteks berbagai macam faktor yang turut mempengaruhi bagaimana menonton atau membaca serta menciptakan makna dari teks.

Secara konseptual khalayak mengkonsumsi media dalam berbagai cara dan kebutuhan. Artikel ini merujuk pada pemikiran interpretif yang menekankan pada pengalaman subyektif (meaning-contruction) seseorang dalam memahami suatu fenomena. Dalam konteks ini, melihat lebih dekat apa yang sebenarnya terjadi pada individu sebagai pengonsumsi teks media dan bagaimana mereka memandang dan memahami teks media ketika berhubungan dengan media.

Media bukan lah sebuah institusi yang memiliki kekuatan besar dalam mempengaruhi khalayak melalui pesan yang disampaikannya. Khalayak lah yang diposisikan sebagai pihak yang memiliki kekuatan dalam menciptakan makna secara bebas dan bertindak atau berperilaku sesuai dengan makna yang mereka ciptakan atas teks media tersebut (Aryani, 2006: 7). Studi mengenai penerimaan media harus menekankan kepada studi mengenai khalayak sebagai bagian dari interpretative communities.

\section{PEMBAHASAN}

Tradisi studi khalayak dalam komunikasi massa mempunyai dua pandangan arus besar (mainstream), pertama khalayak sebagai audience yang pasif. Sebagai audience yang pasif orang hanya bereaksi pada apa yang mereka lihat dan dengar dalam media. Khalayak tidak ambil bagian dalam diskusi-diskusi publik. Khalayak merupakan sasaran media massa. Sementara pandangan kedua khalayak merupakan partisipan aktif dalam publik. Publik merupakan kelompok orang yang terbentuk atas isu tertentu and aktif mengambil bagian dalam diskusi atas isu-isu yang mengemuka.

Tradisi studi khalayak telah dimulai sejak tahun 1930 melalui penelitian efek isi media massa pada sikap publik, dimana institusi media massa merupakan kekuatan besar yang mampu memengaruhi khalayak yang dianggap pasif. Tahun 1960, tradisi studi khalayak bergeser pada perspektif penelitian Uses and Gratifications yang mengedepankan penggunaan media massa oleh khalayak dalam usahanya memenuhi kebutuhan. Khalayak aktif dalam memilih dan menggunakan media. Sementara tahun 1970 terdapat studi budaya dalam hubungannya dengan media massa yaitu 
reception, yang memfokuskan pada hubungan pemaknaan isi media massa dan khalayak, dan tahun 1985 studi komunikasi massa mengenal penelitian media ethnography yang memfokuskan pada rutinitas penggunaan media massa dalam kehidupan sehari-hari. Untuk lebih jelasnya bisa dipetakan sebagai berikut:

\section{Studi Khalayak dalam Komunikasi Massa}

\begin{tabular}{|c|c|c|c|c|}
\hline & $\begin{array}{l}\text { Tradisi } \\
\text { Penelitian } \\
\text { Komunikasi } \\
\text { Massa }\end{array}$ & $\begin{array}{l}\text { Uses And } \\
\text { Gratifications } \\
\text { Research }\end{array}$ & Studi Reception & $\begin{array}{l}\text { Media } \\
\text { Ethnography }\end{array}$ \\
\hline$\overline{\text { Mulai }}$ & 1930 & 1960 & 1970 & 1985 \\
\hline Katakunci & Efek Media & Kebutuhan & Makna & Rutinitas \\
\hline Fokus & $\begin{array}{l}\text { Efek isi media } \\
\text { massa pada } \\
\text { sikap publik }\end{array}$ & $\begin{array}{l}\text { Penggunaan } \\
\text { media massa } \\
\text { untuk memenuhi } \\
\text { kebutuhan } \\
\text { khalayak }\end{array}$ & $\begin{array}{l}\text { Hubungan } \\
\text { antara isi media } \\
\text { massa dan } \\
\text { khalayak }\end{array}$ & $\begin{array}{l}\text { Rutinitas } \\
\text { penggunaan } \\
\text { media massa } \\
\text { dalam kehidupan } \\
\text { sehari-hari }\end{array}$ \\
\hline $\begin{array}{l}\text { Khalayak } \\
\text { dilihat sebagai }\end{array}$ & $\begin{array}{l}\text { Sasaran yang } \\
\text { pasif }\end{array}$ & $\begin{array}{l}\text { Khalayak } \\
\text { sebagai } \\
\text { pengguna media } \\
\text { yang aktif }\end{array}$ & $\begin{array}{l}\text { Khalayak } \\
\text { sebagai active } \\
\text { interpreter }\end{array}$ & $\begin{array}{l}\text { Khalayak } \\
\text { sebagai active } \\
\text { consumer }\end{array}$ \\
\hline Tokoh & Paul Lazarfeld & McQuail & Morley, Ang & Lull, Silverstone \\
\hline
\end{tabular}

Sumber: Lyytikäinen

Artikel ini mengcoba mengupas studi reception dimana khalayak adalah partisipan aktif dalam membangun dan menginterpretasikan makna atas apa yang mereka baca, dengar dan lihat sesuai dengan konteks budaya. Isi media dipahami sebagai bagian dari sebuah proses dimana common sense dikontruksi melalui pembacaan yang diperoleh dari gambar dan teks bahasa. Sementara, makna teks media bukan lah fitur yang transparan, tetapi produk interpretasi oleh pembaca dan penonton (Street, 2001 : 95-97). Asumsinya adalah, sebelumnya media hanya menjadi penyalur informasi, maka kini ia menjadi fasilitator, penyaring dan pemberi makna dari sebuah informasi. Media kini bertugas untuk membawa audience-nya masuk dalam dunia makna yang lebih luas, tidak terbatas pada tempat dan waktu kejadian sebuah peristiwa.

Riset khalayak menurut Stuart Hall (1973) seperti dikutip Baran (2003 :269) mempunyai perhatian langsung terhadap : (a) analisis dalam konteks sosial dan politik dimana isi media diproduksi (encoding); dan (b) konsumsi isi media (decoding) dalam konteks kehidupan sehari-hari. Analisis resepsi memfokuskan pada perhatian individu dalam proses komunikasi massa (decoding), yaitu pada proses pemaknaan dan pemahaman yang mendalam atas media texts, dan bagaimana individu menginterpretasikan isi media (Baran, 2003 : 269-270).

Hal tersebut bisa diartikan individu secara aktif menginterpretasikan teks media dengan cara memberikan makna atas pemahaman pengalamannya sesuai apa yang dilihatnya dalam kehidupan sehari-hari (Verstehen atau understanding). Interpretasi 
didefinisikan sebagai kondisi aktif seseorang dalam proses berpikir dan kegiatan kreatif pencarian makna (Littlejohn, 1999: 199). Sementara makna pesan media tidak lah permanen, makna dikontruksi oleh khalayak melalui komitmen dengan teks media dalam kegiatan rutin interpretasinya. Artinya, khalayak adalah aktif dalam menginterpretasi dan memaknai teks media.

Sementara menurut Lorimer (1994 : 170) melihat pada bagaimana audience merasakan (make sense) media sebagai sebuah produk budaya dan bagaimana interpretasi atas apa yang mereka baca, lihat dan dengar. Proses interpretasi terjadi apabila media mampu memberikan makna tersendiri atas ritual konsumsi media yang dilakukan setiap harinya, dalam konteks sosialnya. Konsumsi isi media mampu memberikan sharing the experience seseorang dengan orang lain melalui tahapan penggunaan media (contexts of media use) dengan interpretasi secara introspeksi, retrospeksi (persepsi), dan pernyataan verbal seseorang atas kegiatannya mengkonsumsi media. Tahapan decodings yaitu pada proses memproduksi makna dan membagikan kepada orang lain. Dalam social contexts konsumsi media cenderung mengkonseptualisasikan media sebagai representasi daripada sebagai sumber informasi. Media terintegrasi kedalam kehidupan sosial seseorang setiap harinya (Jensen, 2002 : 161-163). Media adalah bagian kehidupan sosial manusia, dan manusia terhubung dengan media dalam social settings masing-masing.

\section{METODOLOGI}

\section{Penelitian Khalayak dengan Pendekatan Kualitatif}

Penelitian khalayak dengan pendekatan kualitatif menjadi poin penting dalam studi media dan budaya yang selama ini didominasi oleh pendekatan kuantitatif. Agenda penelitian ini dilakukan untuk memfokuskan pada produksi, teks dan konteks. Makna polisemi teks dan hubungannya dengan khalayak dalam mengintepretasi teks dalam cara yang berbeda-beda menjadi titik yang sangat krusial dalam studi reception. Karena dalam pemaknaan teks, memori individu memberikan arti dalam mengkontruksi dan memahami teks media. Dalam konteks ini, Khun (2002:9) menggunakan istilah 'memory texts' untuk menggambarkan aktivitas yang sudah berlalu dalam mendeteksi, dan mengidentifikasi kembali atas apa yang pernah dilakukan seseorang dalam perspektif konteks perbedaan budaya dan sejarah. Informan melakukan memory work, produksi dan memori dramatisasi atas teks yang dikonsumsinya.

Secara metodologi, reception analysis termasuk dalam paradigma interpretive konstruktivis, dimana menurut Neuman (2000: 71) pendekatan interpretive "is the systematic analysis of socially meaningful action through the direct detailed observation of people in natural settings in order to arrive at understandings and interpretations of how people create and maintain their worlds". Artinya paradigma interpretif dalam konteks penelitian sosial digunakan untuk melakukan interpretasi dan memahami alasan-alasan dari para pelaku terhadap tindakan sosial yang mereka lakukan, yaitu cara-cara dari para pelaku untuk mengkonstruksikan kehidupan mereka dan makna yang mereka berikan kepada kehidupan tersebut.

Argumen tersebut dikembangkan dalam framework studi qualitative empirical reception, yang mana selama dekade lampau telah mempunyai kontribusi secara 
signifikan pada konvergensi antara tradisi penelitian Ilmu Sosial dan Humanistik, yang diartikulasikan kembali dalam batasan pemaknaan atau penerimaan subyektifitas individu dan aktivitas sosial. Reception analysis bukan lah hanya sekedar apa yang lakukan kepada khalayaknya, atau bahkan apa yang khalayak lakukan pada media. Tetapi, pada bagaimana media dan khalayak berinteraksi satu sama lain sebagai agen. Dalam terminologi Semiotika Saussure (1857-1913) merupakan ilmu yang mempelajari the life of signs within society ( Saussure, 1959 : 16). Maknanya adalah dalam pendekatan Semiotik komunikasi dilihat sebagai $a$ mutual negotiation of meaning lebih daripada hanya sekedar pengiriman pesan linear dari pengirim ke penerima.

Reception analysis merujuk pada sebuah komparasi antara analisis tekstual wacana media dan wacana khalayak, yang hasil interpretasinya merujuk pada konteks, seperti cultural setting dan context atas isi media lain (Jensen, 2003 : 139). Khalayak dilihat sebagai bagian dari interpretive communitive yang selalu aktif dalam mempersepsi pesan dan memproduksi makna, tidak hanya sekedar menjadi individu pasif yang hanya menerima saja makna yang diproduksi oleh media massa (McQuail, 1997:19). Reception analysis merupakan studi yang mendalam terhadap proses aktual dimana wacana dalam media diasimilasikan kedalam wacana dan praktik-praktik budaya khalayak. Menurut McQuail (1997), reception analysis menekankan pada penggunaan media sebagai refleksi dari konteks sosial budaya dan sebagai proses dari pemberian makna melalui persepsi khalayak atas pengalaman dan produksi. Hasil penelitian ini merupakan representasi suara khalayak yang mencakup identitas sosial dan posisi subyek.

Setiap individu mempunyai identitas ganda (multiple subject identities), yang secara sadar atau tidak dikontruksi dan dipelihara, termasuk didalamnya umur, ras, gender, kebangsaan, etnisitas, orientasi seksualitas, kepercayaan agama, dan kelas. Misalnya, jika sebuah film mempunyai pesan feminis yang kuat pada penonton akan memberikan penerimaan yang berbeda pada kaum perempuan daripada penonton perempuan yang tidak mempunyai 'rasa' feminis. Hal yang sama, juga pada karya film tentang perjuangan ras akan dimungkinkan 'dibaca atau dimaknai' berbeda oleh khalayak anggota minoritas ras daripada mayoritas. Jadi khalayak akan melihat dan memaknai teks dari posisi subyek berdasarkan persentuhan pengalaman pada saat yang bersamaan.

Harapan pemirsa atas sebuah teks misalnya sebuah film tertentu dapat dipengaruhi oleh apa yang dikenal dengan film's genre; seperti aktor, penulis naskah, sutradara, atau personalia produksi, suasana produksi/ setting, dan sebagainya. Faktor-faktor tersebut sangat mendominasi dalam studi reception. Oleh karena itu, terpenting dan umumnya sulit adalah pada saat mengumpulkan informasi dari para informan untuk menganalisis bagaimana pengalaman khalayak. Peneliti bisa menggunakan teknik pengumpulan data melalui in-depth-interview untuk memperoleh reaksi penerimaan (pemahaman dan interpretasi) mereka atas teks media. Sehingga diharapkan diperoleh informasi atau pendapat yang jujur dan terbuka sesuai dengan tema yang dipilih. Analisisnya adalah narasi-narasi kualitatif yang diperoleh dari hasil interpretasi in-depth interview yang dilaksanakan untuk menjawab permasalahan penelitian. Sedangkan informan bisa dipilih secara purposive dengan mempertimbangkan variasi berdasarkan latarbelakang konteks sosial budaya. 
Seorang peneliti bisa memulai interview informan dengan mempertimbangkan berbagai faktor yang mungkin mempengaruhi seperti bagaimana teks media yang dilihat atau dibaca. Bagaimana pengalaman seseorang atas teks media dari perspektif posisi subjek. Bagaimana makna teks media bagi kelompok umur tertentu, termasuk dari faktor agama, faktor kaum minoritas, faktor sejarah, faktor sosial dan budaya, faktor pendidikan, jenis kelamin, dan sebagainya. Sumber lain yang bisa digunakan untuk mendukung analisis, disamping tinjauan pustaka (konseptual teoritik) dan review literature, adalah dengan membaca surat pembaca ke editor, kolom gosip, artikel surat kabar dan majalah, iklan, press releases, dan bentuk publisitas lain yang mendukung.

Teknik pengumpulan data lain yang bisa dipertimbangkan peneliti adalah dengan melakukan Focus Group Discussion (FGD/ Diskusi Kelompok Terarah) untuk mendapatkan kedalaman. Sehingga lewat FGD dapat diketahui alasan, motivasi, argumentasi atau dasar dari pendapat seseorang. Orang cenderung menjadi lebih nyaman mendiskusikan sebuah topik sebagai bagian dari kelompok. Interaksi antar partisipan dalam membahas sebuah topik menjadi pengamatan menarik peneliti. Misalnya dalam membahas topik film, program televisi, konsumsi dan produksi iklan, dan sebagainya.

\section{KESIMPULAN}

Hal terpenting dalam melakukan penelitian khalayak dengan pendekatan kualitatif menggunakan metode reception analysis adalah informan mempunyai kesempatan yang terbuka dalam menentukan dan mendefinisikan batasan-batasan konsep yang akan dipakai dalam menginterpretasi teks media, karena tipe penelitian yang sifatnya eksploratif membutuhkan kedalaman pemaknaan yang subyektif dari para informan atas teks media berdasarkan konteks. Disamping itu, makna yang merupakan hasil 'interaksi' antara informan sebagai khalayak dengan teks media akan memberikan oportunity to learn peneliti maupun informan dalam menjawab permasalahan.

\section{DAFTAR PUSTAKA}

Aryani, Kandi. 2006. Analisis Penerimaan Remaja terhadap Wacana Pornografi dalam Situs-Situs Seks di Media Online. Jurnal Masyarakat Kebudayaan dan Politik. Tahun XIX. Nomor 2, April. ISSN 0216-2407. Surabaya : FISIP Unair.

Baran, Stanley J. 2003. Mass Communication Theory; Foundations, Ferment, and Future, $3^{\text {rd }}$ edition. Belmon, CA : Thomson

Jensen, Klaus Bruhn. 2002. A Handbook of Media and Communication Research, Qualitative and Quantitative Methodologies. London : Routledge

Jensen, Klaus Bruhn and Nicholas W. Jankowski 2003. A Handbook of Qualitative Methodologies for Mass Communication Research. London : Routledge

Khun, A. 2002. An Everyday Magic: Cinema and Cultural Memory. London : IB Tauris. 
Lyytikäinen, Katariina. Mass Communication. www.media.hut.fi/ as75120/2003/ english_material/final/MassCommunication.pdf, diakses 17 Pebruari 2008.

Lindlof, Thomas R and Bryan C. Taylor. 2002. Qualitative Communication Research Methods. $2^{\text {nd }}$ Edition. London : Sage Publications.

Littlejohn, Stephen W. 1999. Theories Of Human Communication. London : Wadsworth Publishing Company

Lorimer, Rowland. 1994. Mass Communications: A Comparative Introduction. Manchester, UK: Manchester University Press.

McQuail, Denis. 1997. Audience Analysis. London. SAGE Publications, Inc.

Neuman, W. Lawrence. 2000. Social Research Methods: Qualitative and Quantitative Approaches. Needham Height MA : Allyn \& Bacon.

Street, John. 2001. Mass Media, Politics and Society. New York: Palgrave 